Open Access

\title{
Study for selection of industrial areas suitable to small and medium-sized enterprises (SMEs) in Korea
}

\author{
Jun-Hwan Park', Bangrae Lee ${ }^{1,2}$, Yeong-Ho Moon ${ }^{3}$ and Lee-Nam Kwon ${ }^{1 *}$ (D)
}

\author{
* Correspondence: \\ ynkwon@kisti.re.kr \\ ${ }^{1}$ Korea Institute of Science and \\ Technology Information (KISTI), 66 \\ Hoegi-ro, Dongdaemun-gu, Seoul \\ 02456, Republic of Korea \\ Full list of author information is \\ available at the end of the article
}

\begin{abstract}
In this study, the investigation into basic methodology for selecting the industrial areas suitable to the small and medium-sized enterprises (SMEs) in Korea was performed by using the statistical data about the corporations (2010 2012) as the quantitative evidences containing the number of companies, the number of workers, the annual sales, and the indices of market concentration and growth potential. From the Statistics Korea and the KISTI Market Analysis and Prediction System (K-MAPS), the statistical data organized by the Korean Standard Industrial Classification (KSIC) were obtained to conduct this research through the following procedure. First of all, the numbers of enterprises and employees and the annual sales of all industries were investigated and the largest number of workers and the highest annual sales were found in the sector of manufacturing among all sectors of KSIC. Secondly, the top three divisions with the highest annual sales in all divisions of manufacturing sector were selected. Thirdly, the subclasses having high values of annual sales and SMEs proportions among all subclasses in the top three divisions of the previous step were chosen as the candidates of SMEs-recommendable fields. Fourthly, the degree of market concentration was analyzed by using three-firm concentration ratio (CR3) and Herfindahl-Hirschman index (HHI) of the selected subclasses. Finally, the study for growth potential of chosen subclasses was performed through the analysis of compound annual growth rate (CAGR). After the overall process of this study was carried out with the synthetic consideration of the above-mentioned factors, the three subclasses of KSIC as industrial areas suitable to the SMEs could be found: (1) Manufacture of printed circuit boards, (2) Manufacture of parts and accessories for motor engines, and (3) Manufacture of parts and accessories for motor vehicle body. From this result, it was found that the values of annual sales, CR3, HHI, and CAGR can be very useful factors to discover the recommendable industry fields to the SMEs.
\end{abstract}

Keywords: Small and medium-sized enterprises (SMEs), SMEs-suitable areas, Three-firm concentration ratio (CR3), Herfindahl-Hirschman index (HHI), Compound annual growth rate (CAGR)

\section{Introduction}

Promising industry and emerging technology have attracted much attention by government and companies because the innovation of industry and technology is being made with rapid progress under the globalization of world economy. For this reason, government and corporations should find the promising industry and technology appropriate to

(c) 2016 The Author(s). Open Access This article is distributed under the terms of the Creative Commons Attribution 4.0 International License (http://creativecommons.org/licenses/by/4.0/), which permits unrestricted use, distribution, and reproduction in any medium, provided you give appropriate credit to the original author(s) and the source, provide a link to the Creative Commons license, and indicate if changes were made. 
the future demand by obtaining the competitiveness in order to maintain the sustainable growth. To achieve this purpose, the studies for innovation have been widely performed in recent years (Guan and Ma, 2003; Martensen et al., 2007; Tura et al., 2008; Forsman, 2009; Paalanen et al., 2009; Damanpour, 2010; Forsman and Rantanen, 2011; Oganisjana, 2015; Yusr, 2016; Yun et al., 2016). In addition, the effect of research and development (R\&D) support has been studied with great attention (Belderbos et al., 2004; Cassiman and Veugelers, 2005; Czarnitzki et al., 2007; Aerts and Schmidt, 2008; Hussinger, 2008; Czarnitzki and Hottenrott, 2011; Takalo et al., 2013; Kang and Cho, 2016; Kim et al., 2016). In order to accomplish the innovation capability and the R\&D support in the perspective of small and medium-sized enterprises (SMEs) for finding the prospective areas, they depends on the announcement of promising industry and technology from government and public institutions. Since the SMEs have the limitations of manpower and resources, it is difficult for them to search for the promising fields autonomously. However, many fields of industry and technology which are not suitable to the SMEs are included in the prospective areas presented by government and public institutions. This is because the procedure to choose the promising industry and technology by government and public institutions is mostly dependent on the opinion of experts (ex. Delphi method). Also, in Korea, the polarization between large corporations and SMEs has not been solved yet. It is induced by rapid expansion of business field for major companies. Therefore, for the survival of SMEs in present and future market, it is necessary to develop the basic methodology of finding the SMEs-recommendable areas.

Hottenrott and Lopes-Bento (2014) investigated the impact and the influence of targeted public R\&D support in the level of company and they observed the effect of policy-induced $R \& D$ investment on the sales from the market novelties in the viewpoint of international collaborators and SMEs. In addition, they found the contribution of $R \& D$ support from public subsidies to innovation performance of SMEs. Saunila and Ukko (2014) studied the intangible factors in the innovation capability of SMEs by utilizing a web-based questionnaire. The results from their research demonstrated that the intangible aspects in the innovation capability of SMEs are not influenced by their size and industry. Due to this reason, the SMEs are able to have a higher potential for innovation than major companies. Ahmedova (2015) carried out the research for the factors to improve the competitiveness of SMEs. In this reference, the reason for the focal point on the SMEs was that their business areas are very significant to develop the national economics. It is because the SMEs have the great potential of flexible adaptation to market situation. The author found the main features helpful to enhance the competitiveness of companies: access to finance, innovation activities, internationalization, and so on.

The goal of this research is the establishment of basic methodology for selecting the candidates of promising fields appropriate to the SMEs in Korea systemically by utilizing the statistical data as the quantitative evidences. For achievement of this purpose, annual sales, three-firm concentration ratio (CR3), Herfindahl-Hirschman index (HHI), and compound annual growth rate (CAGR) of corporations were used and the analyses for those factors were performed with the Korean Standard Industrial Classification (KSIC). 


\section{Data and methodology \\ Data}

Two kinds of statistical data were used in this study: (1) public data (2010) gained in the Statistics Korea and (2) processed data (2010 2012) in the KISTI Market Analysis and Prediction System (K-MAPS). Both data are based on the KSIC. The KSIC is the systematic classification for industrial activities of Korean corporations according to their similarity. There are 5 levels in the KSIC composed of sector (1-digit level, alphabet), division (2-digit level), group (3-digit level), class (4-digit level), and subclass (5-digit level) and the numbers of each level are 21, 76, 228, 487, and 1,145, respectively. The statistical data of all firms in Korea including their data (ex. the number of companies, the number of employees, the annual sales, the business profits, and so on) could be obtained from the Korean Statistical Information Service (KOSIS) which is a core service site of the Statistics Korea. For the production of this public data, the Economic Census for investigation of all enterprises by the Statistics Korea is being performed in every 5 years. Therefore, the statistical data for 2010 is the newest now and the data about 2015 will be provided in 2017 after the survey for all enterprises of Korea in 2016. For this reason, the public data for all companies of 2010 was used in this research. Furthermore, the data for subclass level of manufacturing sector of KSIC related to market analysis (ex. annual sales, CR3, and HHI) could be gained from the K-MAPS site. Those data about market analysis from 2010 to 2012 were produced by utilizing the database of corporate finance (about 370,000 companies in the manufacturing sector) provided by the Korea Enterprise Data (KED).

\section{Methodology}

In this research, four factors (annual sales, three-firm concentration ratio (CR3), Herfindahl-Hirschman index (HHI), compound annual growth rate (CAGR) of sales) having effects on the selection of industrial areas suitable to the SMEs were considered and they are listed with their definition and usefulness (Table 1). By taking account of those factors synthetically, the industrial areas appropriate for the SMEs in Korea were chosen through the following process. First of all, the number of enterprises, the number of workers, and the annual sales of all KSIC sectors in 2010 were utilized to find the industrial area with the highest values of those factors because they can be the typical indicators for measuring the market size of each industrial field. Secondly, among all divisions of manufacturing sector found as the industrial area having the largest number of employees and the highest annual sales, top three divisions with the

Table 1 Introduction to various factors influencing the selection of SMEs-recommendable industry areas based on the KSIC

\begin{tabular}{|c|c|c|}
\hline Factor & Definition & Usefulness \\
\hline Annual sales & $\begin{array}{l}\text { Amount of income from selling goods } \\
\text { or providing services during } 1 \text { year }\end{array}$ & $\begin{array}{l}\text { One of the representative indicators } \\
\text { for the market size of industry }\end{array}$ \\
\hline $\begin{array}{l}\text { Three-firm concentration } \\
\text { ratio (CR3) }\end{array}$ & $\begin{array}{l}\text { Total market share (\%) of top three } \\
\text { companies }\end{array}$ & $\begin{array}{l}\text { Evidence for the degree of market } \\
\text { concentration }\end{array}$ \\
\hline Herfindahl-Hirschman Index $(\mathrm{HHI})$ & $\begin{array}{l}\text { Sum of squared value of market } \\
\text { share percentage }\end{array}$ & $\begin{array}{l}\text { Evidence for the degree of market } \\
\text { concentration }\end{array}$ \\
\hline $\begin{array}{l}\text { Compound Annual Growth Rate } \\
\text { (CAGR) of sales }\end{array}$ & $\begin{array}{l}\text { Mean annual growth rate of sales } \\
\text { over a specified period of time }\end{array}$ & $\begin{array}{l}\text { Evidence for the growth potential } \\
\text { of industry }\end{array}$ \\
\hline
\end{tabular}


highest value of annual sales were selected. Thirdly, the annual sales and the SMEs proportions were used as indices to choose the industrial areas among all subclasses in the top three divisions. Fourthly, the values of CR3 and HHI from 2010 to 2012 were employed for analyzing the market concentration of chosen subclasses in the manufacturing sector of KSIC. The details of CR3 and HHI will be explained in the next section. Finally, the CAGR of sales (period of time: $2010 \sim 2012$ ) was used to figure out the growth potential of selected subclasses. After the procedure of this basic methodology, it was possible to find the SMEs-recommendable industrial areas.

\section{$\mathrm{CR} 3$ and $\mathrm{HHI}$}

The value for $\mathrm{CR}$ is the sum of market shares from a specified number of companies (Calkins, 1983). In this research, the CR3 (CR value of three largest firms in the market share) was utilized and this can be gained by using the following equation.

$$
\mathrm{CR} 3(\%)=\sum_{i=1}^{3} \mathrm{MS}_{i}
$$

In this formula, the $\mathrm{MS}_{i}$ means the market share of individual enterprise with the $i$ th highest value. The higher value of CR3 for a certain market area indicates that the market is more concentrated. However, the value of CR3 has a limitation in its application for analyzing the market concentration because the remaining corporates excluding top 3 firms are not considered (Sys, 2009). To compensate this deficiency of CR3, the value of $\mathrm{HHI}$ is also used in the analysis of the market concentration and it can be calculated from the following equation (Calkins, 1983).

$$
\mathrm{HHI}=\sum_{i=1}^{n} \mathrm{MS}_{i}{ }^{2}
$$

In this equation, $n$ is the number of companies and the unit of $\mathrm{MS}_{i}$ value is the percentage. As presented in Equation (2), the market shares of all enterprises are considered in obtaining the value of HHI. Thus, both CR3 and HHI should be taken into account for analyzing the market concentration. Furthermore, the HHI value can be utilized as a criterion showing the degree of market concentration (Calkins, 1983; Sys, 2009; Titilayo and Victor, 2014). (1) When the HHI value is lower than 1,000, the market is unconcentrated. (2) The value of HHI between 1000 and 1800 indicates the moderate concentration of market. (3) When the HHI value is 1800 or more, it means that the market is highly concentrated. In order to find the SMEs-recommendable industry areas by using the statistical data about companies, the values of CR3 and HHI showing the degree of market concentration were utilized in this research.

\section{Results and discussion}

Investigation into the statistical data for all enterprises in the levels of sector and division of the KSIC

The numbers of companies and employees and the annual sales of all industries and 21 sectors of KSIC could be obtained by using the statistical data of 2010 from the KOSIS of the Statistics Korea (Table 2). In addition, the proportions for those components were calculated. As presented in Table 2, the most numerous employees $(3,417,698$ 
Table 2 Numbers of companies and employees and annual sales of all industries and sectors (2010)

\begin{tabular}{|c|c|c|c|c|c|c|c|}
\hline KSIC code & $\begin{array}{l}\text { Sector of KSIC in } \\
\text { all industries }\end{array}$ & $\begin{array}{l}\text { (a) Number } \\
\text { of companies }\end{array}$ & $\begin{array}{l}\text { Ratio of } \\
\text { (a) (\%) }\end{array}$ & $\begin{array}{l}\text { (b) Number } \\
\text { of employees }\end{array}$ & $\begin{array}{l}\text { Ratio of } \\
\text { (b) }(\%)\end{array}$ & $\begin{array}{l}\text { (c) Annual sales } \\
\text { (Million won) }\end{array}$ & $\begin{array}{l}\text { Ratio of } \\
\text { (c) }(\%)\end{array}$ \\
\hline & All industries & $3,355,470$ & 100.00 & $17,647,028$ & 100.00 & $4,332,292,658$ & 100.00 \\
\hline A & $\begin{array}{l}\text { Agriculture, forestry, } \\
\text { and fishing }\end{array}$ & 2354 & 0.07 & 30,418 & 0.17 & $9,207,983$ & 0.21 \\
\hline B & Mining and quarrying & 1770 & 0.05 & 16,377 & 0.09 & $3,650,007$ & 0.08 \\
\hline C & Manufacturing & 326,813 & 9.74 & $3,417,698$ & 19.37 & $1,464,336,545$ & 33.80 \\
\hline D & $\begin{array}{l}\text { Electricity, gas, steam, } \\
\text { and water supply }\end{array}$ & 1499 & 0.04 & 66,267 & 0.38 & $120,556,744$ & 2.78 \\
\hline$E$ & $\begin{array}{l}\text { Sewerage, waste } \\
\text { management, materials } \\
\text { recovery, and remediation } \\
\text { activities }\end{array}$ & 5402 & 0.16 & 69,132 & 0.39 & $14,474,084$ & 0.33 \\
\hline $\mathrm{F}$ & Construction & 96,833 & 2.89 & $1,180,659$ & 6.69 & $271,063,929$ & 6.26 \\
\hline G & Wholesale and retail trade & 876,654 & 26.13 & $2,617,891$ & 14.83 & $819,828,179$ & 18.92 \\
\hline $\mathrm{H}$ & Transportation & 347,179 & 10.35 & 992,546 & 5.62 & $147,571,423$ & 3.41 \\
\hline | & $\begin{array}{l}\text { Accommodation and food } \\
\text { service activities }\end{array}$ & 634,500 & 18.91 & $1,766,290$ & 10.01 & $77,682,506$ & 1.79 \\
\hline J & $\begin{array}{l}\text { Information and } \\
\text { communications }\end{array}$ & 26,375 & 0.79 & 468,585 & 2.66 & $115,566,239$ & 2.67 \\
\hline K & $\begin{array}{l}\text { Financial and insurance } \\
\text { activities }\end{array}$ & 39,353 & 1.17 & 706,859 & 4.01 & $744,138,697$ & 17.18 \\
\hline L & $\begin{array}{l}\text { Real estate activities and } \\
\text { renting and leasing }\end{array}$ & 126,081 & 3.76 & 440,556 & 2.50 & $64,305,803$ & 1.48 \\
\hline M & $\begin{array}{l}\text { Professional, scientific, } \\
\text { and technical activities }\end{array}$ & 70,601 & 2.10 & 750,393 & 4.25 & $117,677,853$ & 2.72 \\
\hline N & $\begin{array}{l}\text { Business facilities } \\
\text { management and business } \\
\text { support services }\end{array}$ & 35,910 & 1.07 & 788,674 & 4.47 & $36,393,804$ & 0.84 \\
\hline O & $\begin{array}{l}\text { Public administration and } \\
\text { defense; compulsory social } \\
\text { security }\end{array}$ & 11,929 & 0.36 & 663,673 & 3.76 & $97,290,425$ & 2.25 \\
\hline P & Education & 165,964 & 4.95 & $1,420,892$ & 8.05 & $84,001,584$ & 1.94 \\
\hline Q & $\begin{array}{l}\text { Human health and social } \\
\text { work activities }\end{array}$ & 107,012 & 3.19 & $1,084,758$ & 6.15 & $69,552,877$ & 1.61 \\
\hline R & $\begin{array}{l}\text { Arts, sports, and recreation } \\
\text { related services }\end{array}$ & 102,948 & 3.07 & 322,881 & 1.83 & $34,228,991$ & 0.79 \\
\hline S & $\begin{array}{l}\text { Membership organizations, } \\
\text { repair, and other personal } \\
\text { services }\end{array}$ & 376,293 & 11.21 & 842,479 & 4.77 & $40,764,985$ & 0.94 \\
\hline $\mathrm{T}$ & $\begin{array}{l}\text { Activities of households as } \\
\text { employers; undifferentiated } \\
\text { goods- and services- } \\
\text { producing activities of } \\
\text { households for own use }\end{array}$ & N/A & N/A & N/A & N/A & N/A & N/A \\
\hline U & $\begin{array}{l}\text { Activities of extraterritorial } \\
\text { organizations and bodies }\end{array}$ & N/A & N/A & N/A & N/A & N/A & N/A \\
\hline
\end{tabular}

Since the properties of sector $\mathrm{T}$ and $\mathrm{U}$ are not applicable to compute the numbers of companies and employees and the sales, the values for them were not provided by the Statistics Korea

Data source: Economic Census, Korean Statistical Information Service (KOSIS) which is a core service site of the Statistics Korea (http://kosis.kr)

people, $19.37 \%)$ and the highest annual sales (1,464,336,545 million won, $33.80 \%)$ of Korea in 2010 were found in the sector of manufacturing. From this statistical data, it is expected that the industrial area concerned with the manufacturing was the main field of Korea industry in 2010. Therefore, the manufacturing sector of KSIC was chosen to research for the basic methodology to discover the appropriate industry area of SMEs in Korea. 
To find the top 3 divisions having the highest annual sales in 2010 among all divisions in the manufacturing sector, the values of their annual sales were compared (Table 3). The division in the first place for the annual sales was the KSIC code 26 (Manufacture of electronic components, computer, radio, television, and communication equipment and apparatuses, $17.98 \%$ ). As the second place, the KSIC code 30 (Manufacture of motor vehicles, trailers, and semitrailers) was observed (10.39\%). The KSIC code 24 (Manufacture of basic metal products) was in the third place (10.11\%). By utilizing these results, those three divisions were chosen for studying the proportion of SMEs in the annual sales.

\section{Research for the selected subclasses of manufacturing sector}

In order to examine the ratio of SMEs in the annual sales of 2010 among all subclasses contained in the top three divisions selected from Table 3, the values of annual sales

Table 3 Annual sales and their ratio of manufacturing sector and its 24 divisions (2010)

\begin{tabular}{|c|c|c|c|}
\hline KSIC code & Division in the manufacturing sector of $\mathrm{KSIC}$ & $\begin{array}{l}\text { Annual sales } \\
\text { (Million won) }\end{array}$ & Ratio (\%) \\
\hline C & Manufacturing & $1,464,336,545$ & 100.00 \\
\hline 10 & Manufacture of food products & $66,303,956$ & 4.53 \\
\hline 11 & Manufacture of beverages & $8,047,923$ & 0.55 \\
\hline 12 & Manufacture of tobacco products & $3,100,366$ & 0.21 \\
\hline 13 & Manufacture of textiles, except apparel & $26,372,142$ & 1.80 \\
\hline 14 & Manufacture of wearing apparel, clothing accessories, and fur articles & $23,015,703$ & 1.57 \\
\hline 15 & Tanning and dressing of leather, manufacture of luggage and footwear & $5,958,998$ & 0.41 \\
\hline 16 & Manufacture of wood and of products of wood and cork; except furniture & $6,603,706$ & 0.45 \\
\hline 17 & Manufacture of pulp, paper and paper products & $22,855,447$ & 1.56 \\
\hline 18 & Printing and reproduction of recorded media & $7,914,757$ & 0.54 \\
\hline 19 & $\begin{array}{l}\text { Manufacture of coke, hard-coal and lignite fuel briquettes, and refined } \\
\text { petroleum products }\end{array}$ & $113,218,854$ & 7.73 \\
\hline 20 & $\begin{array}{l}\text { Manufacture of chemicals and chemical products except pharmaceuticals } \\
\text { and medicinal chemicals }\end{array}$ & $124,063,180$ & 8.47 \\
\hline 21 & $\begin{array}{l}\text { Manufacture of pharmaceuticals, medicinal chemicals, and botanical } \\
\text { products }\end{array}$ & $14,210,794$ & 0.97 \\
\hline 22 & Manufacture of rubber and plastic products & $60,710,165$ & 4.15 \\
\hline 23 & Manufacture of other non-metallic mineral products & $37,852,453$ & 2.58 \\
\hline 24 & Manufacture of basic metal products & $148,078,592$ & 10.11 \\
\hline 25 & Manufacture of fabricated metal products, except machinery and furniture & $82,730,945$ & 5.65 \\
\hline 26 & $\begin{array}{l}\text { Manufacture of electronic components, computer, radio, television, and } \\
\text { communication equipment and apparatuses }\end{array}$ & $263,295,000$ & 17.98 \\
\hline 27 & $\begin{array}{l}\text { Manufacture of medical, precision, optical instruments, and watches } \\
\text { and clocks }\end{array}$ & $18,242,154$ & 1.25 \\
\hline 28 & Manufacture of electrical equipment & $70,066,678$ & 4.78 \\
\hline 29 & Manufacture of other machinery and equipment & $107,261,402$ & 7.32 \\
\hline 30 & Manufacture of motor vehicles, trailers, and semitrailers & $152,108,349$ & 10.39 \\
\hline 31 & Manufacture of other transport equipment & $83,082,252$ & 5.67 \\
\hline 32 & Manufacture of furniture & $12,359,000$ & 0.84 \\
\hline 33 & Other manufacturing & $6,883,729$ & 0.47 \\
\hline
\end{tabular}

Data source: Economic Census, Korean Statistical Information Service (KOSIS) which is a core service site of the Statistics Korea (http://kosis.kr) 
were computed by using the analysis service of K-MAPS and the subclasses with relatively high annual sales were listed in Table 4. The reason for utilizing analysis service of the K-MAPS is that it provides the annual sales of individual corporates operating in the industrial fields related to the manufacturing sector of KSIC by using the business finance database of about 370,000 companies purchased from the KED. Furthermore, the value of market share for each company can be calculated by utilizing its annual sales (In the next section, the analysis for market concentration will be discussed.). Also, the values of annual sales for individual corporates are not provided in the KOSIS. For these reasons, the analysis of statistical data about each company in the KMAPS was performed instead of that in the KOSIS. In addition, the number of workers was utilized to distinguish the SMEs in this study. The criterion number of employees in the manufacturing sector in order to separate the SMEs from the large enterprises is 300 people by applying the Basic Law for SMEs of Korea from 2010 to 2012. In other words, the number of employees in a corporate should be less than 300 people to be recognized as a SME of Korea in the sector of manufacturing from 2010 to 2012.

As listed in Table 4, most subclasses showed higher ratio of SMEs than $20 \%$ in the annual sales but the subclasses having very low proportions of SMEs in the annual sales were also found. From these results, total 5 subclasses with very low ratios of SMEs were excluded in the further analysis of market concentration: the KSIC code (1) 24211 (Manufacture of smelting, refining, and alloys of copper, $6 \%$ ), (2) 26120 (Manufacture of diodes, transistors, and similar semi-conductor devices, $13 \%$ ), (3)

Table 4 Annual sales and their proportion of SMEs for the chosen subclasses (2010)

\begin{tabular}{|c|c|c|c|}
\hline KSIC code & Subclass in the manufacturing sector of KSIC & $\begin{array}{l}\text { Annual sales } \\
\text { (Million won) }\end{array}$ & $\begin{array}{l}\text { Proportion of } \\
\text { SMEs (\%) }\end{array}$ \\
\hline 24121 & Manufacture of hot rolled, drawn, and extruded iron or steel products & $6,425,208$ & 23 \\
\hline 24132 & Manufacture of pipes and tubes of non-cast iron or steel & $13,902,211$ & 22 \\
\hline 24191 & Manufacture of guilt, coloration, surface processing steel materials & $2,162,861$ & 24 \\
\hline 24211 & Manufacture of smelting, refining, and alloys of copper & $8,945,571$ & 6 \\
\hline 24221 & Manufacture of rolled, drawn, and folded products of copper & $6,033,576$ & 26 \\
\hline 24222 & Manufacture of rolled, drawn, and folded products of aluminum & $7,151,018$ & 34 \\
\hline 26110 & Manufacture of electronic integrated circuits & $6,346,772$ & 27 \\
\hline 26120 & Manufacture of diodes, transistors, and similar semi-conductor devices & $24,335,270$ & 13 \\
\hline 26211 & Manufacture of liquid crystal flat display boards & $51,354,130$ & 4 \\
\hline 26221 & Manufacture of printed circuit boards & $6,579,265$ & 44 \\
\hline 26422 & Manufacture of mobile phone & $148,261,264$ & 0.4 \\
\hline 26511 & Manufacture of television & $2,972,917$ & 21 \\
\hline 30121 & Manufacture of passenger motor vehicles & $80,394,434$ & 0.01 \\
\hline 30310 & Manufacture of parts and accessories for motor engines & $9,379,206$ & 32 \\
\hline 30320 & Manufacture of parts and accessories for motor vehicle body & $9,071,525$ & 59 \\
\hline 30391 & Manufacture of power transmission for motor vehicles & $6,849,358$ & 31 \\
\hline 30392 & Manufacture of electrical equipment for motor vehicles & $1,446,523$ & 50 \\
\hline
\end{tabular}

The selected subclasses showed high annual sales among all subclasses contained in the top 3 divisions with the largest annual sales in Table 3 (2010): (1) Manufacture of electronic components, computer, radio, television, and communication equipment and apparatuses (17.98\%, KSIC code 26), (2) Manufacture of motor vehicles, trailers, and semitrailers ( $10.39 \%$, KSIC code 30$)$, and (3) Manufacture of basic metal products $(10.11 \%$, KSIC code 24$)$

In Korea, to be recognized as a SME in the manufacturing sector, the number of employees should be less than 300 people (Application of the Basic Law for SMEs of Korea from 2010 to 2012)

Data source: Analysis of market concentration, KISTI Market Analysis and Prediction System (K-MAPS) (http://kmaps.kisti.re.kr) 
26211 (Manufacture of liquid crystal flat display boards, $4 \%$ ), (4) 26422 (Manufacture of mobile phone, 0.4\%), and (5) 30121 (Manufacture of passenger motor vehicles $0.01 \%$ ). Also, the subclasses with "other" term in their designations were also excluded (not shown in Table 4) because they include so many kinds of industrial areas which cannot be classified elsewhere in the subclasses of KSIC: the KSIC code (1) 24199 (Manufacture of other basic iron and steel n. e. c.), (2) 26429 (Manufacture of other wireless telecommunication apparatuses), and (3) 30399 (Manufacture of other parts and accessories for motor vehicles n. e. c.). Through the above-mentioned process, total 12 subclasses were selected for the analysis of their market concentration.

\section{Analysis of the market concentration for the selected subclasses}

For studying the market concentration from 2010 to 2012 based on the annual sales of individual enterprises in the level of KSIC subclass, the processed data for the values of CR3 and HHI computed by utilizing the market share of individual corporates in the K-MAPS were used. As listed in Table 5, there were four subclasses showing the high values of HHI larger than 1800 with relatively high CR3 (from 56 to $94 \%$ ): the KSIC code (1) 24132 (Manufacture of pipes and tubes of non-cast iron or steel), (2) 24191 (Manufacture of guilt, coloration, surface processing steel materials), (3) 24221 (Manufacture of rolled, drawn, and folded products of copper), and (4) 26511 (Manufacture of television). These four subclasses were removed from the list of industrial areas appropriate to the SMEs because the values of CR3 and HHI should be low for the initial market penetration of SMEs. Also, it is expected that the market competition of the SME with other SMEs is much easier than that with major corporates having relatively high values of annual sales and market share. Therefore,

Table 5 Values of CR3 and HHI for the selected subclasses (2010 2012)

\begin{tabular}{|c|c|c|c|c|c|c|c|}
\hline \multirow[t]{2}{*}{ KSIC code } & \multirow[t]{2}{*}{ Subclass in the manufacturing sector of KSIC } & \multicolumn{3}{|c|}{ CR3 (\%) } & \multicolumn{3}{|l|}{$\mathrm{HHI}$} \\
\hline & & 2010 & 2011 & 2012 & 2010 & 2011 & 2012 \\
\hline 24121 & $\begin{array}{l}\text { Manufacture of hot rolled, drawn, and extruded iron } \\
\text { or steel products }\end{array}$ & 35 & 35 & 37 & 770 & 786 & 836 \\
\hline 24132 & Manufacture of pipes and tubes of non-cast iron or steel & 59 & 57 & 57 & 2326 & 2210 & 2148 \\
\hline 24191 & $\begin{array}{l}\text { Manufacture of guilt, coloration, surface processing steel } \\
\text { materials }\end{array}$ & 75 & 72 & 72 & 2833 & 2587 & 2467 \\
\hline 24221 & $\begin{array}{l}\text { Manufacture of rolled, drawn, and folded products } \\
\text { of copper }\end{array}$ & 58 & 56 & 57 & 1809 & 1686 & 1785 \\
\hline 24222 & $\begin{array}{l}\text { Manufacture of rolled, drawn, and folded products } \\
\text { of aluminum }\end{array}$ & 47 & 48 & 47 & 1254 & 1309 & 1214 \\
\hline 26110 & Manufacture of electronic integrated circuits & 39 & 39 & 40 & 1020 & 1069 & 1056 \\
\hline 26221 & Manufacture of printed circuit boards & 22 & 22 & 24 & 944 & 936 & 925 \\
\hline 26511 & Manufacture of television & 89 & 78 & 94 & 5909 & 3866 & 7459 \\
\hline 30310 & Manufacture of parts and accessories for motor engines & 29 & 30 & 31 & 820 & 797 & 784 \\
\hline 30320 & $\begin{array}{l}\text { Manufacture of parts and accessories for motor } \\
\text { vehicle body }\end{array}$ & 19 & 19 & 20 & 677 & 643 & 644 \\
\hline 30391 & Manufacture of power transmission for motor vehicles & 44 & 46 & 48 & 1253 & 1455 & 1621 \\
\hline 30392 & Manufacture of electrical equipment for motor vehicles & 51 & 53 & 50 & 1163 & 1239 & 1226 \\
\hline
\end{tabular}

As presented in Table 4, the chosen subclasses had $20 \%$ or more proportion of SMEs in the annual sales Data source: Analysis of market concentration, KISTI Market Analysis and Prediction System (K-MAPS) (http://kmaps.kisti.re.kr) 
it is important to analyze the statistical data relevant to the market environment including annual sales, CR3, and HHI synthetically in the level of KSIC subclass in order to discover the promising industry fields for the SMEs.

\section{Study for tendency and CAGR of the annual sales from 2010 to 2012}

In order to perform the analysis for growth potential of the selected subclasses from Table 5, the tendency and the CAGR of annual sales from 2010 to 2012 were computed as listed in Table 6. For the discovery of SMEs-recommendable industry fields, the value of CAGR should be relatively high and the sales from 2010 to 2012 should be increased continuously. Among total 8 subclasses remaining in the previous step, very low values of CAGR were observed in three subclasses: the KSIC code (1) 24121 (Manufacture of hot rolled, drawn, and extruded iron or steel products, $1.01 \%$ ), (2) 24222 (Manufacture of rolled, drawn, and folded products of aluminum, $-0.06 \%$ ), and (3) 26110 (Manufacture of electronic integrated circuits, $0.61 \%$ ). In addition, the high value of CAGR was found in the KSIC code 30391 (Manufacture of power transmission for motor vehicles, $10.92 \%$ ) but its annual sales from 2010 to 2012 did not show the continuous increment. From these results, total 4 subclasses with the high value of CAGR and the continuous increase in the annual sales were selected as the candidates of suitable areas to the SMEs: the KSIC code (1) 26221 (Manufacture of printed circuit boards, $14.89 \%$ ), (2) 30310 (Manufacture of parts and accessories for motor engines, $9.16 \%$ ), (3) 30320 (Manufacture of parts and accessories for motor vehicle body, $9.17 \%$ ), and (4) 30392 (Manufacture of electrical equipment for motor vehicles, $16.18 \%$ ).

\section{Selection of SMEs-recommendable industrial areas}

For the discovery of industrial fields appropriate to the SMEs, the values of annual sales, CR3, HHI, and CAGR should be taken into account synthetically. From this perspective, the subclass with the KSIC code 30392 (Manufacture of electrical

Table 6 Annual sales and their values of CAGR for the chosen subclasses (2010 2012)

\begin{tabular}{|c|c|c|c|c|c|}
\hline \multirow[t]{2}{*}{ KSIC code } & \multirow[t]{2}{*}{ Subclass in the manufacturing sector of KSIC } & \multicolumn{3}{|c|}{ Annual sales (Million won) } & \multirow[t]{2}{*}{ CAGR (\%) } \\
\hline & & 2010 & 2011 & 2012 & \\
\hline 24121 & $\begin{array}{l}\text { Manufacture of hot rolled, drawn, and extruded } \\
\text { iron or steel products }\end{array}$ & $6,425,208$ & $6,988,439$ & $6,555,231$ & 1.01 \\
\hline 24222 & $\begin{array}{l}\text { Manufacture of rolled, drawn, and folded products } \\
\text { of aluminum }\end{array}$ & $7,151,018$ & $7,554,277$ & $7,142,339$ & -0.06 \\
\hline 26110 & Manufacture of electronic integrated circuits & $6,346,772$ & $6,587,213$ & $6,424,311$ & 0.61 \\
\hline 26221 & Manufacture of printed circuit boards & $6,579,265$ & $7,480,920$ & $8,684,789$ & 14.89 \\
\hline 30310 & $\begin{array}{l}\text { Manufacture of parts and accessories for } \\
\text { motor engines }\end{array}$ & $9,379,206$ & $11,077,627$ & $11,175,734$ & 9.16 \\
\hline 30320 & $\begin{array}{l}\text { Manufacture of parts and accessories for motor } \\
\text { vehicle body }\end{array}$ & $9,071,525$ & $10,709,960$ & $10,811,588$ & 9.17 \\
\hline 30391 & $\begin{array}{l}\text { Manufacture of power transmission for } \\
\text { motor vehicles }\end{array}$ & $6,849,358$ & $8,516,331$ & $8,426,627$ & 10.92 \\
\hline 30392 & $\begin{array}{l}\text { Manufacture of electrical equipment for } \\
\text { motor vehicles }\end{array}$ & $1,446,523$ & $1,805,942$ & $1,952,468$ & 16.18 \\
\hline
\end{tabular}

As listed in Table 5, the selected subclasses showed the HHI values lower than 1800 Data source: Analysis of market concentration, KISTI Market Analysis and Prediction System (K-MAPS) (http://kmaps.kisti.re.kr) 
equipment for motor vehicles) could not be listed in the industrial fields suitable to the SMEs because of its relatively high values of CR3 (51, 53 and $50 \%)$ and HHI (1163, 1239 and 1226) from 2010 to 2012 compared to those of other three subclasses (The KSIC code 26221, 30310, and 30320). According to the position of SMEs, it is possible for them to choose the appropriate fields through the following two ways. The first one is that the SMEs can select the industrial area with higher CAGR when their first consideration is in its growth potential. In this case, the subclass of the KSIC code 26221 (Manufacture of printed circuit boards) is able to become the best field by following the basic methodology of this study. On the other hand, the second one is that the SMEs preferentially consider the stable entrance to the initial market having lower value of HHI. For this objective, the SMEs can choose the subclasses of the KSIC code 30310 (Manufacture of parts and accessories for motor engines) and 30320 (Manufacture of parts and accessories for motor vehicle body) as their prospective areas through the selection procedure of SMEs-recommendable industry area from this research. Thus, the SMEs can discover the suitable fields by applying their realistic position and purpose to the basic methodology of this study.

\section{Conclusions and future work}

This research was performed for the establishment of the basic methodology utilizing the statistical data as quantitative evidences. Through the overall procedure of this study, it was possible to select the SMEs-recommendable industry fields by considering their annual sales, market consideration (CR3 and HHI), and growth potential (CAGR). From the results of this study, it was found that those factors can be used as indicators to find the industrial areas suitable to the SMEs in Korea. However, the methodology of this study has the potential limits because it is difficult to reflect the market situation which can be changed suddenly in the near future. In order to overcome this defect, it is necessary to develop the methodology of this study as a further work under the consideration of more factors such as the business profits, the information about the number of enterprises founded or closed, the analysis of emerging industry/technology, and so on. Through the continuous development of the basic methodology studied in this study for the discovery of industrial areas appropriate to the SMEs, it will be very helpful for them to select the specific industry field with the value of investment having high annual sales or business profits, low market concentration, great potential of growth, and so on. Furthermore, from this research, the following influences on the SMEs can be accomplished: (1) improvement in their capabilities of business planning, (2) progress of their innovation, and (3) enhancement of investment efficiency in the national $R \& D$ for them.

Acknowledgement

This research was supported by the research project (Activation of research and development services through the establishment of information analysis platform, K-16-L02-C04-S01) funded by the Ministry of Science, ICT and Future Planning of Korea.

Authors' contributions

All authors read and approved the final manuscript. 


\section{Author details}

${ }^{1}$ Korea Institute of Science and Technology Information (KISTI), 66 Hoegi-ro, Dongdaemun-gu, Seoul 02456, Republic of Korea. ${ }^{2}$ University of Seoul, 163 Seoulsiripdae-ro, Dongdaemun-gu, Seoul 02504, Republic of Korea. ${ }^{3}$ Korea Institute of Science and Technology Information (KISTI), 245 Daehak-ro, Yuseong-gu, Daejeon 34141, Republic of Korea.

Received: 6 July 2016 Accepted: 3 September 2016

Published online: 27 September 2016

References

Aerts, K., \& Schmidt, T. (2008). Two for the price of one? Additionality effects of R\&D subsidies: a comparison between Flanders and Germany. Research Policy, 37, 806-822.

Ahmedova, S. (2015). Factors for Increasing the Competitiveness of Small and Medium-Sized Enterprises (SMEs) In Bulgaria. Procedia - Social and Behavioral Sciences, 195, 1104-1112.

Analysis of market concentration, KISTI Market Analysis and Prediction System (K-MAPS) (http://kmaps.kisti.re.kr) Accessed 23 May 2016.

Belderbos, R., Carree, M., \& Lokshin, B. (2004). Cooperative R\&D and firm performance. Research Policy, 33, 1477-1492.

Calkins, S. (1983). The New Merger Guidelines and the Herfindahl-Hirschman Index. California Law Review, 71(2), 402-429.

Cassiman, B., \& Veugelers, R. (2005). R\&D cooperation between firms and universities. Some empirical evidence from Belgian manufacturing. International Journal of Industrial Organization, 23, 355-379.

Czarnitzki, D., Ebersberger, B., \& Fier, A. (2007). The relationship between R\&D collaboration, subsidies and R\&D performance: empirical evidence from Finland and Germany. Journal of Applied Econometrics, 22(7), 1347-1366.

Czarnitzki, D., \& Hottenrott, H. (2011). R\&D investment and financing constraints of small and medium-sized firms. Small Business Economics, 36(1), 65-83.

Damanpour, F. (2010). An integration of research findings of effects of firm size and market competition on product and process innovations. British Journal of Management, 21(4), 996-1010.

Economic Census, Korean Statistical Information Service (KOSIS) which is a core service site of the Statistics Korea (http://kosis.kr). Accessed 23 May 2016.

Forsman, H. (2009). Improving innovation capabilities of small enterprises: cluster strategy as a tool. International Journal of Innovation Management, 13(2), 221-243.

Forsman, H., \& Rantanen, H. (2011). Small manufacturing and service enterprises as innovators: a comparison by size. European Journal of Innovation Management, 14(1), 27-50.

Guan, J., \& Ma, N. (2003). Innovative capability and export performance of Chinese firms. Technovation, 23, 737-747.

Hottenrott, H., \& Lopes-Bento, C. (2014). (International) R\&D collaboration and SMEs: The effectiveness of targeted public R\&D support schemes. Research Policy, 43, 1055-1066.

Hussinger, K. (2008). R\&D and subsidies at the firm level: an application of parametric and semiparametric two-step selection models. Journal of Applied Econometrics, 23(6), 729-747.

Kang, J., \& Cho, S. (2016). A study on the accountability of the regional R\&D program: the case of APCTP. Journal of Open Innovation: Technology, Market, and Complexity, 2, 3.

Kim, S.-j., Kim, E.-m., Suh, Y., \& Zheng, Z. (2016). The effect of service innovation on R\&D activities and government support systems: the moderating role of government support systems in Korea. Journal of Open Innovation: Technology, Market, and Complexity, 2, 5.

Martensen, A., Dahlgaard, J. J., Park-Dahlgaard, S. M., \& Grønholdt, L. (2007). Measuring and diagnosing innovation excellence-simple contra advanced approaches: a Danish study. Measuring Business Excellence, 11(4), 51-65.

Oganisjana, K. (2015). Promotion of university students' collaborative skills in open innovation environment. Journal of Open Innovation: Technology, Market, and Complexity, 1, 18

Paalanen, A., Kujansivu, P., Parjanen, S. (2009). Measuring the effects of an innovation-focused intervention. The Future of Innovation: Proceedings of the XX ISPIM 2009 Conference, June 2009, Vienna, Austria.

Saunila, M., \& Ukko, J. (2014). Intangible aspects of innovation capability in SMEs: Impacts of size and industry. Journal of Engineering and Technology Management, 33, 32-46.

Sys, C. (2009). Is the container liner shipping industry an oligopoly? Transport Policy, 16, 259-270.

Takalo, T., Tanayama, T., \& Toivanen, O. (2013). Estimating the benefits of targeted R\&D subsidies. Review of Economics and Statistics, 95(1), 255-272

Titilayo, B. O., \& Victor, O. T. (2014). Bank Consolidation and Market Structure in Nigeria: Application of the HerfindahlHirschman Index. International Journal of Economics and Finance, 6(2), 235-243.

Tura, T., Harmaakorpi, V., \& Pekkola, S. (2008). Breaking inside the black box: towards a dynamic evaluation framework of regional innovative capability. Science and Public Policy, 35(10), 733-744.

Yun, J. J., Won, D., \& Park, K. (2016). Dynamics from open innovation to evolutionary change. Journal of Open Innovation: Technology, Market, and Complexity, 2, 7.

Yusr, M. M. (2016). Innovation capability and its role in enhancing the relationship between TQM practices and innovation performance. Journal of Open Innovation: Technology, Market, and Complexity, 2, 6. 